ОЦІНКА ІНВЕСТИЦІЙНОЇ ПРИВАБЛИВОСТІ ЗАЛІЗНИЧНОГО ТРАНСПОРТУ УКРАЇНИ

\title{
ESTIMATION OF INVESTMENT ATTRACTIVENESS OF RAILWAY TRANSPORT OF UKRAINE
}

УДК656.2:658.152(043.2)

https://doi.org/10.32843/infrastruct35-22

\section{Васильєв О.л.}

к.е.н., доцент,

доцент кафедри менеджменту

і адміністрування

Український державний університет

залізничного транспорту

Нікітін В.A.

студент

Український державний університет

залізничного транспорту

Тесленко В.М.

студент

Український державний університет залізничного транспорту
У статті визначено, що активізація інвестиційної діяльності залізниць України $\epsilon$ необхідною передумовою їхнього сталого розвитку, модернізації і структурної перебудови, що неможливе без підвищення їхньоі інвестиційної привабливості. Узагальнено та розподілено на групи підходи до тлумачення сутності поняття «інвестиційна привабливість». Запропоновано визначення терміна «інвестиційна привабливість залізничного транспорту». Визначено показники, що можуть застосовуватися як параметри виробничого та фрінансово-економічного стану залізничного транспорту під час оцінки його інвестиційної привабливості. Запропоновано методичний підхід до інтегральної оцінки інвестиційної привабливості залізниць та їхніх структурних підрозділів з урахуванням основних параметрів виробничого та фрінансово-економічного стану, їхньої значущості та відповідності кожного параметра певному рівню, який визначається інвестором. Проаналізовано чинники, що впливають на сучасний стан діяльності залізничного транспорту. Розроблено заходи щодо підвищення інвестиційної привабливості залізниць.

Ключові слова: інвестиції, інвестиційна діяльність, інвестиційна привабливість, оцінка, залізничний транспорт.

В статье определено, что активизация инвестиционной деятельности железных дорог Украины является необходимым условием их устойчивого развития, модернизации и структурной пере- стройки, что невозможно без повышения их инвестиционной привлекательности. Обобщены и распределены на группы подходы к толкованию сущности понятия «инвестиционная привлекательность». Предложено определение термина «инвестиционная привлекательность железнодорожного транспорта». Обобщены подходы к толкованию сущности понятия «инвестиционная привлекательность» и приведено определение инвестиционной привлекательности железнодорожного транспорта. Определены показатели, которые могут применяться в качестве параметров производственного и финансово-экономического состояния желез нодорожного транспорта при оценке его инвестиционной привлекательности Предложен методический подход к интегральной оценке инвестиционной привлекательности железных дорог и их структурных подразделений с учетом основных параметров производственного и фринансово-экономического состояния, их зна чимости и соответствия каждого параметра определенному уровню, который определяется инвестором. Проанализированы фракторы, влияющие на современное состояние деятельности железнодорожного транспорта. Разработаны мероприятия по повышению инвестиционной привлекательности железных дорог.

Ключевые слова: инвестиции, инвестиционная деятельность, инвестиционная привлекательность, оценка, железнодорожный транспорт.

It is determined that activation of the investment activity of the Ukrainian railways is a necessary prerequisite for their sustainable development, modernization and structural restructuring, which is impossible without providing a favorable investment climate and enhancing their investment attractiveness. Approaches to interpreting the essence of the term "investment attractiveness" have been generalized and divided into groups. It is proposed to determine the investment attractiveness of the railway transport as an integral assessment of the most important parameters of its production and financial and economic condition, which allows the potential investor to make a management decision on the feasibility of investing free funds in the development of the railway industry without significant risk of loss or loss of profit. The groups of indicators that can be used as parameters of the production and financial and economic condition of railway transport in assessing its investment attractiveness are determined. A potential investor can use both all the indicators as a whole and a combination of these, depending on the goals that he or she sets for investing, in assessing the investment attractiveness of the railway or its structural units. In addition, this list may be supplemented by other indicators. A methodological approach to the integral evaluation of the investment attractiveness of the railways and their structural subdivisions is proposed, taking into account the basic parameters of the production and financial and economic status, their importance and the correspondence of each parameter to a certain level, which is determined by the investor. This methodological approach allows to determine the indicator both for railway transport in general, and in terms of types of activity, farms, individual subdivisions of railways. It is determined that the characteristic features of the current state of railway transport activity is a high level of deterioration of rolling stock and material and technical base, a critical level of financial state of the industry, as well as open questions about privatization, development of public-private partnerships, attracting investments, technical innovations and technological modernization in industry. It is investigated that the reasons for this situation are insufficient state support, limited amount of own funds of railways, limited external sources of financing. A set of measures was developed to increase the investment attractiveness of the railways.

Key words: investments, investment activity, investment attractiveness, rating, railway transport.

Постановка проблеми. Стабільність розвитку національної економіки залежить від ступеня розвитку кожної з ії галузей та інфраструктурних елементів. Ефективний розвиток залізничного транспорту $€$ необхідною умовою для сталого фрункціонування всіх галузей економіки, забезпечення статусу України як великої транзитної держави, сприяння її соціальному й економічному зростанню, економічній безпеці та обороноздат- ності. Активізація інвестиційної діяльності залізниць України $є$ необхідною передумовою їхнього сталого розвитку, модернізації і структурної перебудови, що неможливе без забезпечення сприятливого інвестиційного клімату та підвищення їхньої інвестиційної привабливості. В умовах реформування залізничного транспорту України проблеми підвищення його інвестиційної привабливості стають особливо актуальними. Ïх ефек- 
тивне вирішення сприятиме зростанню інвестиційного потенціалу галузі.

Аналіз останніх досліджень і публікацій. Питання інвестиційної діяльності на залізничному транспорті розглянуто у працях вітчизняних науковців: О.Г. Дейнеки, Л.О. Позднякової, В.Л. Диканя, Є.М. Сича, М. Чеховської [1-5] та ін. Однак у працях вищезгаданих вчених оцінюванню рівня інвестиційної привабливості залізничного транспорту, який має певні галузеві особливості, приділяється недостатня увага.

Постановка завдання. Метою статті $\epsilon$ комплексне оцінювання рівня інвестиційної привабливості залізниць України та їхніх структурних підрозділів.

Виклад основного матеріалу дослідження. В економічній літературі дотепер не вироблений єдиний підхід до визначення сутності поняття «інвестиційна привабливість». Аналіз підходів до визначення сутності інвестиційної привабливості, що наявні сьогодні, дає можливість розподілити їх на три основні групи:

1) трактування інвестиційної привабливості як інтегральної характеристики об'єкта потенційно можливого інвестування (І.О. Бланк, В.Л. Іванов, С. Лоза, Т.В. Майорова [6-9] та ін.);

2) трактування інвестиційної привабливості як сукупності певного набору характеристик об'єкта потенційно можливого інвестування (В.П.Савчук, С.І. Прилипко, Є.Г. Величко, Н. Макарій, В.А. Соболь, І.В. Кошилєв [10-12] та ін.).

3) трактування інвестиційної привабливості як характеристики економіко-психологічної задоволеності інвестора (А.Я. Єлович, Н.С. Краснокутська, В.С. Михайлов, О.В. Крехівський [13-15] та ін.).

Узагальнюючи все розмаїття підходів до тлумачення сутності інвестиційної привабливості та акцентуючи увагу на залізничному транспорті, автори пропонують розглядати інвестиційну привабливість залізничного транспорту як інтегральну оцінку найважливіших параметрів його виробничого та фрінансово-економічного стану, яка дає змогу потенційному інвестору прийняти управлінське рішення щодо доцільності вкладення вільних коштів у розвиток залізничної галузі без значного ризику їх втрати або неотримання очікуваного розміру інвестиційного прибутку.

Як параметри виробничого та фрінансово-економічного стану залізничного транспорту під час оцінки його інвестиційної привабливості пропонується розглядати такі групи показників:

1) загальні показники:

- темпи зростання загальних результатів діяльності (обсягів перевезення вантажів і пасажирів, вантажообігу і пасажирообігу, чистого прибутку);

- рівень загальної рентабельності;

- коефіцієнт фрінансової стійкості;

- коефіцієнт платоспроможності;

- темпи зростання собівартості вантажних і пасажирських перевезень;
2) часткові показники:

- темпи зростання продуктивності праці;

- коефіцієнт співвідношення темпів зростання продуктивності праці та темпів зростання заробітної плати;

- частка приросту обсягів перевезень у результаті зростання продуктивності праці;

- фрондовіддача;

- рівень зносу основних фрондів;

- коефіцієнт обігу оборотних коштів;

3) якісні показники:

- рівень якості послуг;

- стабільність персоналу.

Потенційний інвестор під час оцінки інвестиційної привабливості залізничного транспорту або його структурних підрозділів може використовувати як усі показники загалом, так і їх певну комбінацію залежно від цілей, які він ставить перед інвестуванням. Крім того, цей перелік може бути доповнений й іншими показниками.

Оцінювання інвестиційної привабливості залізничного транспорту або його структурних підрозділів передбачає такі етапи:

- визначення параметрів виробничого та фрінансово-економічного стану залізничного транспорту, що будуть використовуватися під час оцінки його інвестиційної привабливості;

- числовий вимір і часові обмеження параметрів;

- встановлення експертним шляхом значущості кожного параметра у загальній їх кількості (сума вагомостей дорівнює 1);

- визначення ступеня відповідності кожного параметра певному рівню, який визначається інвестором;

- розрахунок інтегральної оцінки інвестиційної привабливості;

- прийняття управлінського рішення щодо доцільності інвестування.

Інтегральну оцінку інвестиційної привабливості залізничного транспорту або його структурних підрозділів пропонується розраховувати за фрормулою:

$$
\mathrm{I \Pi}_{3 \mathrm{~T}}=\frac{\sum_{\mathrm{i}=1}^{1} \gamma_{\mathrm{i}} \mathrm{n}_{\mathrm{i}}}{\mathrm{N}},
$$

де I - кількість параметрів виробничого та фрінансово-економічного стану залізничного транспорту, що використовуються під час оцінки його інвестиційної привабливості;

$\mathrm{y}_{i}$ - значущість і-того параметра виробничого та фрінансово-економічного стану залізничного транспорту, яка може суттєво змінюватися залежно від умов і цілей, які ставить перед собою інвестор;

$\mathrm{n}_{\mathrm{i}}$ - оцінка інвестором і-того параметра за певною шкалою (п'ятибальною, десятибальною, стобальною або іншою);

$\mathrm{N}$ - загальна максимальна оцінка інвестиційної привабливості залізничного транспорту або його структурних підрозділів за певною шкалою. 
Оцінку і-того параметра за певною шкалою можна виконати таким чином

$$
\mathrm{n}_{\mathrm{i}}=\frac{\mathrm{n}_{\mathrm{i}}^{\phi} \cdot \mathrm{N}}{\mathrm{n}_{\mathrm{i}}^{\mathrm{e}}},
$$

де $n_{i}^{\phi}$ - середнє значення i-того параметра серед фрактично отриманих за певний проміжок часу;

$\mathrm{n}_{\mathrm{i}}^{\mathrm{e}}$ - еталонне значення і-того параметра, яке розглядає інвестор.

Під час використання десятибальної шкали отримані результати розрахунку пропонується розглядати в таких інтервалах:

- ІІ привабливості;

- ІІ зт від 6 до 8 - середній рівень інвестиційної привабливості;

- ІП вт від 8 до 10 - високий рівень інвестиційної привабливості.

Відповідно ці інтервали можна перерахувати і для будь-якої іншої шкали.

Цей методичний підхід до оцінки інвестиційної привабливості дає змогу визначити показник як для AT «Укрзалізниця» загалом, так і в розрізі видів діяльності, господарств, окремих підрозділів залізниць.

Характерними рисами сучасного стану діяльності залізничного транспорту $€$ високий рівень зношення рухомого складу і матеріально-технічної бази, критичний рівень фрінансового стану галузі, а також відкриті питання щодо приватизації, розвитку державно-приватного партнерства, залучення інвестицій, технічних інновацій і технологічної модернізації в галузі.

Подібну ситуацію можна пояснити такими причинами. По-перше, практично повною відсутністю державної підтримки. По-друге, недоліком власних коштів залізниць. По-третє, відсутністю (недоліком) зовнішніх джерел фрінансування.

Крім зазначених проблем діяльності залізничного транспорту, необхідно виділити також невирішені питання щодо задоволення потреб економіки, такі як невідповідність якості обслуговування вантажовласників та пасажирів європейським вимогам, низька швидкість перевезень, постійне збільшення частки транспортної складової у собівартості продукції, значний ступінь державного регулювання залізничного сектору економіки тощо.

Результатом зазначених процесів є насамперед зниження економічних вигід діяльності транспорту 3 боку як власних інтересів, так і інтересів держави. Це не тільки спричиняє уповільнення темпів економічного розвитку держави, але й ускладнює на сучасному етапі присутність України на світовому ринку транспортних послуг.

Всебічне вивчення стану залізничного транспорту дає змогу виділити такий комплекс заходів, щодо підвищення його інвестиційної привабливості:

- удосконалення організаційно-управлінських заходів: впровадження ефективної системи управління, поліпшення якісного складу керівництва, розроблення інвестиційної стратегії, орієнтованої на потенційних інвесторів;

- поліпшення фрінансового стану: залучення довгострокових позикових джерел, розвиток лізингових операцій, зниження короткострокової кредиторської заборгованості;

- збільшення прибутковості: удосконалення тарифної політики, зниження умовно-постійних витрат, збільшення рентабельності власного капіталу;

- підвищення есрективності використання ресурсів: зниження рівня зносу тягового рухомого складу, підвищення показника фрондовіддачі, зниження енергоємності продукції, зниження чисельності управлінського персоналу, зростання продуктивності праці, поліпшення обсягових і якісних показників роботи;

- удосконалення організаційно-технічних заходів: удосконалення технології виробництва, поліпшення показника технічної озброєності, підвищення рівня інфрорматизації та автоматизації, удосконалення мотивації праці, спрямованої на участь працівників у результатах діяльності, поліпшення показників охорони праці й охорони навколишнього середовища.

Висновки 3 проведеного дослідження. Підвищення ефективності роботи залізничного транспорту Україні передбачає наявність ефективної інвестиційної політики, яка би враховувала геополітичні, економічні і соціальні особливості функціонування залізничної галузі та її роль у загальнодержавних процесах, а також надала б можливість збільшувати інвестиційний потенціал галузі, підвищувати ії інвестиційну привабливість, фрормувати нові механізми взаємодії 3 інвесторами, здійснювати галузеві проекти, які мають найбільшу економічну і комерційну еорективність і є привабливими для інвесторів.

Інтегральна оцінка інвестиційної привабливості залізниць повинна враховувати основні параметри їхнього виробничого та фрінансово-економічного стану, значущість кожного параметра та його відповідність певному рівню, який визначається інвестором. Це дає змогу визначити показник як для залізничного транспорту загалом, так і в розрізі видів діяльності, господарств, окремих підрозділів залізниць.

Об'єктивна оцінка інвестиційної привабливості залізничного транспорту дає змогу потенційному інвестору прийняти зважене управлінське рішення щодо доцільності вкладення вільних коштів у розвиток залізничної галузі без значного ризику їх втрати або неотримання очікуваного розміру інвестиційного прибутку.

Подальші дослідження в цьому напрямі будуть спрямовані на кількісну оцінку окремих показників, що можуть застосовуватися як параметри виробничого та фрінансово-економічного стану залізничного транспорту під час оцінки його інвестиційної привабливості та визначення ступеня їхньої вагомості. 


\section{БІБЛІОГРАФІЧНИЙ СПИСОК:}

1. Дейнека О.Г. Інноваційно-інвестиційні підходи до розвитку галузі залізничного транспорту. Вісник економіки транспорту і промисловості. 2008. № 22. C. 54-55.

2. Позднякова Л.О, Моцная І.В. Шляхи підвищення інвестиційної привабливості залізниць України. Вісник економіки транспорту і промисловості. 2008. № 22. С. 74-75.

3. Дикань В.Л., Зубенко В.О. Забезпечення ефективності інноваційної діяльності підприємств залізничного транспорту. Харків : УкрДАЗТ, 2008. 193 с.

4. Сич Є.М., Ільчук В.П. Інноваційно-інвестиційний розвиток залізничного транспорту. Київ : Логос, 2001. 256 c.

5. Чеховська М. Інвестиційні та інноваційні напрями подальшого розвитку залізничного транспорту. Економіст. 2009. № 11. С. 57-59.

6. Бланк И.А. Управление инвестициями предприятия. Киев : Эльга: Ника-Центр, 2003. 479 с.

7. Іванов В.Л. Аналіз інвестиційної привабливості на основі комплексної оцінки фрінансово-економічної діяльності. Економіка, менеджмент, підприємництво. 2001. № 6. С. 11-15.

8. Лоза С.В. Інвестиційна привабливість (країни, регіону, підприємства). Схід. 2005. № 9. С. 54-57.

9. Майорова Т.В. Інвестиційна діяльність навчальний посібник. Київ : ЦМЛ, 2004. 376 с.

10. Савчук В.П., Прилипко С.И., Величко Е.Г. Анализ и разработка инвестиционных проектов : учебное пособие. Киев : Абсолют-В; Эльга, 1999. 304 с.

11. Макарій Н. Оцінка інвестиційної привабливості українських підприємств. Економіст. 2001. № 10. С. 52-61.

12. Соболь В.А., Кошилєв І.В. Управління інвестиційними процесами. Економіка та держава. 2006. № 10. С. 31-33.

13. Краснокутська Н.С. Оцінка інвестиційної привабливості. Бізнес інфоорм. 2000. № 4. С. 62-65.

14.Елович А.Я. Интегральная оценка инвестиционной привлекательности и критериев эффрективности проекта фрирмы. Культура народов Причерноморья. 2003. № 45. С. 38-41.

15. Михайлов В.С., Крехівський О.В. Статистичн оцінки інвестиційної привабливості підприємств і організацій окремих регіонів, фрорм власності та галузей економіки. Статистика України. 2000. № 3. С. 18-26.

\section{REFERENCES:}

1. Dejneka O. Gh. (2008) Innovacijno-investycijni pidkhody do rozvytku ghaluzi zaliznychnogho transportu [Innovation and investment approaches to the development of the railway industry]. Visnyk ekonomiky transportu i promyslovosti, no. 22, pp. 54-55. (in Ukrainian)

2. Pozdnjakova L. O, Mocnaja I. V. (2008) Shljakhy pidvyshhennja investycijnoji pryvablyvosti zaliznycj Ukrajiny [Ways to increase the investment attractive- ness of Ukrainian railways]. Visnyk ekonomiky transportu i promyslovosti, no. 22, pp. 74-75. (in Ukrainian)

3. Dykanj V. L., Zubenko V. O. (2008) Zabezpechennja efektyvnosti innovacijnoji dijaljnosti pidpryjemstv zaliznychnogho transportu [Ensuring efficiency of innovative activity of railway transport enterprises]. Kharkiv: UkrDAZT. (in Ukrainian)

4. Sych Je. M., Iljchuk V. P. (2001) Innovacijnoinvestycijnyj rozvytok zaliznychnogho transportu [Railway transport innovation and investment development]. Kyjiv: Loghos. (in Ukrainian)

5. Chekhovsjka M. (2009) Investycijni ta innovacijni naprjamy podaljshogho rozvytku zaliznychnogho transportu [Investment and innovation directions for further development of railway transport]. Ekonomist, no. 11. pp. 57-59.

6. Blank I. A. (2003) Upravlenie investitsiyami predpriyatiya [Enterprise Investment Management]. Kiev: El'ga: Nika-Tsentr. (in Russian)

7. Ivanov V. L. (2001) Analiz investycijnoji pryvablyvosti na osnovi kompleksnoji ocinky finansovo-ekonomichnoji dijaljnosti [Analysis of investment attractiveness based on a comprehensive assessment of financial and economic activity]. Ekonomika, menedzhment, pidpryjemnyctvo, no. 6, pp. 11-15. (in Ukrainian)

8. Loza S. V. (2005) Investycijna pryvablyvistj (krajiny, reghionu, pidpryjemstva) [Investment attractiveness (countries, regions, enterprises)]. Skhid. no. 9, pp. 54-57. (in Ukrainian)

9. Majorova T. V. (2004) Investycijna dijaljnistj: navchaljnyj posibnyk [Investment activity: a textbook]. Kyjiv: CML. (in Ukrainian)

10. Savchuk V. P., Prilipko S. I., Velichko E. G. (1999) Analiz i razrabotka investitsionnykh proektov: uchebnoe posobie [Analysis and development of investment projects: a training manual]. Kiev: Absolyut-V; El'ga. (in Russian)

11. Makarij N. (2001) Ocinka investycijnoji pryvablyvosti ukrajinsjkykh pidpryjemstv [Assessment of investment attractiveness of Ukrainian enterprises]. Ekonomist, no. 10, pp. 52-61. (in Ukrainian)

12. Sobolj V. A., Koshyljev I. V. (2006) Upravlinnja investycijnymy procesamy [Management of investment processes]. Ekonomika ta derzhava, no. 10, pp. 31-33. (in Ukrainian)

13. Krasnokutsjka N. S. (2000) Ocinka investycijnoji pryvablyvosti [Assessment of investment attractiveness]. Biznes inform, no. 4, pp. 62-65. (in Ukrainian)

14. Elovich A. Ya. (2003) Integral'naya otsenka investitsionnoy privlekatel'nosti i kriteriev effektivnosti proekta firmy [Integral assessment of investment attractiveness and criteria for the effectiveness of a firm's project]. Kul'tura narodov Prichernomor'ya, no. 45, pp. 38-41. (in Russian)

15. Mykhajlov V. S., Krekhivsjkyj O. V. (2000) Statystychni ocinky investycijnoji pryvablyvosti pidpryjemstv i orghanizacij okremykh reghioniv, form vlasnosti ta ghaluzej ekonomiky [Statistical evaluations of investment attractiveness of enterprises and organizations of particular regions, forms of ownership and industries]. Statystyka Ukrajiny, no. 3, pp. 18-26. (in Ukrainian) 


\section{Vasyliev Oleg \\ Candidate of Economic Sciences, Associate Professor, Senior Lecturer at Department of Management and Administration Ukrainian State University of Railway Transport \\ Nikitin Vladyslav Student Ukrainian State University of Railway Transport Teslenko Vitalii Student \\ Ukrainian State University of Railway Transport}

\section{ESTIMATION OF INVESTMENT ATTRACTIVENESS OF RAILWAY TRANSPORT OF UKRAINE}

The purpose of the article. The intensification of investment activities of Railways of Ukraine is a necessary precondition for sustainable development, modernization and restructuring, which is impossible without ensuring a favorable investment climate and increase investment attractiveness. As an objective assessment of investment attractiveness is one of the key factors influencing the decision of potential investors, this question has been extensively debated in the works of representatives of different economic schools. In Ukraine in the conditions of reforming of railway transport problems of increasing its investment attractiveness are particularly relevant. An effective solution will promote growth of investment potential of the industry.

Methodology. For the analysis of the current status of the activities of railway transport of Ukraine and generalization of world experience of development of railway transport, the authors used methods of system analysis and synthesis, methods of induction and deduction were used to summarize the approaches to interpretation of essence of concept "investment attractiveness" and the definition of investment attractiveness of the railway transport; the method of formalization used for integral estimation of investment attractiveness of the Railways and their divisions.

Results. Approaches to interpreting the essence of the term "investment attractiveness" have been generalized and divided into groups. It is proposed to determine the investment attractiveness of the railway transport as an integral assessment of the most important parameters of its production and financial and economic condition, which allows the potential investor to make a management decision on the feasibility of investing free funds in the development of the railway industry without significant risk of loss or loss of profit. The groups of indicators that can be used as parameters of the production and financial and economic condition of railway transport in assessing its investment attractiveness are determined. A potential investor can use both all the indicators as a whole and a combination of these, depending on the goals that he or she sets for investing, in assessing the investment attractiveness of the railway or its structural units. In addition, this list may be supplemented by other indicators. A methodological approach to the integral evaluation of the investment attractiveness of the railways and their structural subdivisions is proposed. It is determined that the characteristic features of the current state of railway transport activity is a high level of deterioration of rolling stock and material and technical base, a critical level of financial state of the industry, as well as open questions about privatization, development of public-private partnerships, attracting investments, technical innovations and technological modernization in industry. It is investigated that the reasons for this situation are insufficient state support, limited amount of own funds of railways, limited external sources of financing. A set of measures was developed to increase the investment attractiveness of the railways.

Practical implications. Methodical approach to evaluation of investment attractiveness allows you to define the index for rail transportation in General and in the context of activities of the farms, individual units of the Railways. In contrast to existing methodological approaches it takes into account the basic parameters of production and financial-economic condition of Railways and their divisions, the significance of each parameter and its compliance to a certain level, which is determined by the investor. Objective evaluation of investment attractiveness of railway transport and its subdivisions gives an opportunity to a potential investor to make an informed management decision about the advisability of investing available funds in the development of the railway industry without significant risk of loss or non-receipt of the expected size of the investment income.

Value/originality. In our work we have considered the issue of investment attractiveness of railway transport. Further studies in this direction will be aimed at quantifying the individual indicators that can be used as parameters of the production and financial and economic status of railway transport in assessing its investment attractiveness, and determining the degree of their importance. 